\title{
Pregnancy-Associated Plasma Protein-A Measurement
}

National Cancer Institute

\section{Source}

National Cancer Institute. Pregnancy-Associated Plasma Protein-A Measurement. NCI

Thesaurus. Code C82031.

The determination of the amount of pregnancy-associated plasma protein-A present in a sample. 